\title{
Wagnerianism in the Czech Lands in the 1880s
}

\author{
Marek Pechač
}

The principal aim of this paper is an attempt to articulate a concise insight into problems of Wagnerian reception in 1880s in the Czech Lands. In this decade it is possible to emphasize several milestones which incited multifarious disputations about Richard Wagner's work and about his influence on Czech national music. Among these events belonged the opening of Prague's National Theatre (hereafter Národní divadlo), the premiere of Parsifal in Bayreuth, the first nights of Zdeněk Fibich's Nevěsta Messinská [The Bride of Messina] and Wagner's Lohengrin in the Národní divadlo and the putting on of Lohengrin and Tannhäuser in the Municipal Theatre in Pilsen.

Before we focus our attention on these component points, it is also necessary to mention the latest diatribe of Antiwagnerianism which is dated from 1881 when František Pivoda (1824-1898) published a book $O$ hudbě Wagnerově [About Wagner's Music]. Nevertheless this event did not provoke any notable reaction. For instance in the music periodical Dalibor the publication of this book was only reflected in the subtle remark of Hynek Palla (1837-1896) who mentioned-on the occasion of recalling that older endeavours of describing Wagnerianism in Czech music were non-patriotic and alien-that " $[. .$. yet recently have arisen noticeable, but weak traces of it in the public."' The publication did not become a source of another polemic, which was caused also by Pivoda's isolation, in which he found himself because of an accusation that his diatribes became one of the reasons for Bedřich Smetana's turning deaf.

In the same year the opening of the Národní divadlo with the long-awaited premiere of the opera Libuše sparked many press responses. Otakar Hostinský in an article "Smetanova Libuše" [Smetana's Libuše], which was published approximately a month before the first night, declared that disputes about Wagner were finished. According to Hostinský, Libuše was inspired by Wagner much more distinctly than Dalibor was, but he considered the contemporaneous audience to be better prepared for the music, because it had already

\footnotetext{
Hynek Palla, "Šírení vědomostí o hudbě" [The Spread of Knowledge about Music], Dalibor, 3 (1881),
} No. 20, p. 156. 
comprehended that "[...] being Wagnerian [...] does not alienate any composer from the national art." ${ }^{2}$ A few days after the festive premiere Emanuel Chvála (1851-1924) reported on a "healthy Wagnerianism", which Smetana espoused in his Libuše, because only "[...] in the manner of setting the words to music was Wagner Smetana's ideal." ${ }^{3}$ Also Palla declared Libuše to be "a splendid deed" of endeavouring to assert the principles of Wagner's operatic reform and he simultaneously emphasized that "[...] the same result which Wagner gained [from the reform] of German opera, we will gain-on the basis of artistic, not German principles-for our Czech opera."

In 1882 readers of Dalibor were intimately informed about the premiere of Parsifal in Bayreuth in three comprehensive articles by Eduard Moučka (1865-1937). He wrote the first treatise about Parsifal before the first night of the work, which-according to his words-he had already heard several times with piano accompaniment, however with a full cast in choral and soloists' parts. The following two articles Moučka wrote after he attended probably the first three public performances of Parsifal. He talked about a completely new kind of work of art and exhorted readers to travel to Bayreuth so as not to miss the opportunity to see "[...] the royal beauties of this festive play." In the concluding summary of the work Moučka expressed the following conviction: "I do not doubt that Parsifal will have a substantial impact on the development of any nation's domestic art, which therefore does not have to lose its unique character." Similar opinions about the significance of the influence of Wagner's works on Czech national music very often appeared in several sources. This resulted from the differentiation of Wagner the theorist and reformer from Wagner the musician and poet, which was indicated for the first time in 1871 by Hostinský in his treatise Wagnerianismus a česká národní opera [Wagnerianism and Czech National Opera].

In the following year many responses were aroused by the unexpected death of Richard Wagner on 13 February 1883. The report on his demise arrived in Prague one day later. This event markedly influenced Prague's cultural life in the following few weeks: Let us mention for instance the production of Wagner's composition from 1843, Das Liebesmahl der Apostel, by the Hlahol choir on 18 February, ${ }^{7}$ Hostinský's discourse about Wagner organized by the music section of the Umělecká beseda [Artists' Circle] on 28 February and the concert of Wagner's music arranged by the Filharmonie [Philharmonic] on 11 March.

Otakar Hostinský, "Smetanova 'Libuše”, Dalibor, 3 (1881), No. 17, p. 133.

3 Emanuel Chvála, "Otevření Národního divadla" [The Opening of the National Theatre], Dalibor, 3 (1881), No. 18, p. 140.

4 Hynek Palla, "Šíření vědomostí o hudbě: Dokončení" [The Spread of Knowledge about Music: Conclusion], Dalibor, 3 (1881), No. 20, p. 157.

5 Eduard Moučka, "R. Wagnera Parsifal II.: Dokončeni” [R. Wagner’s Parsifal II.: Conclusion], Dalibor, 4 (1882), No. 26, p. 204.

6 Ibid.

7 Although the programme of the concert was given before Wagner's death, the performance was perceived as a tribute to him. 
Played in the concert were-among other items-excerpts from Parsifal and from all parts of the tetralogy Der Ring des Nibelungen, and the evening was closed by the overture from Tannhäuser. A reviewer in Dalibor criticized the program as some kind of tedious monotony; nonetheless the audience professedly "[...] persisted [...] really up to the end [...] with piety owing to the remembrance of a man who has such a huge significance in the

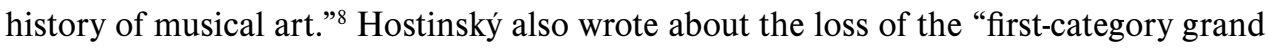
spirit", expressing an opinion that "[...] a stark, commonsensible historical point of view will now become $[. .$.$] easier than it has been so far."$

The name Otakar Hostinský also emerged in impassioned debates about Fibich's "music drama” Nevěsta Messinská. Hostinský-apart from being the author of the libretto, participated significantly as a publicist on breaking ground for the premiere of the work. The main expedient was again the journal Dalibor, representing an ideology close to Hostinský's own aesthetic persuasion. Already in early 1884 Dalibor had published five of Hostinsky's articles containing a comprehensive analysis of the opera. Rather surprising is his astonishment about the fact that this Schiller drama had never been used as a basis for opera, if we realize that Hostinský was the leading Czech adherent of Wagner's theoretical principles, though in his interpretation partly modified..$^{10}$ Let us mention that Nevěsta Messinská is precisely one of those examples that Wagner mentioned as dramas which are not appropriate for setting to music. ${ }^{11}$ The premiere of Nevěsta Messinská on 28 March 1884 was described as an exceptional success and an everlasting triumph for all that members of our audience did not know Wagner's modern style and that it was unfamiliar to them; in other words, as the lodestar of Fibich's work called the reviewer the "[...] melodramatic style of Wagner's last period", which included Der Ring des Nibelungen and Parsifal according to him..$^{12}$ Břetislav Lvovský $(1857-1910)$ in the following years in Dalibor labelled Nevěsta Messinská our own first music drama, probably comparable only with Tristan. ${ }^{13}$ Dalibor's orientation of opinion nevertheless exemplified a representative view neither of the Czech music critique nor of general public opinion. Before the premiere Karel Knittl (1853-1907) published in the pages of Národní listy [National Gazette] his misgiving that "[...] the incessant gloomy mood of the whole [...] poem will scarcely be supportive to the listener's taste". ${ }^{14}$ Straightaway in the first review of Fibich's work-proceeding very cautiously-Knittl emphasized above all the various reactions of spectators, emerging from their attitude to the phenomenon of Wagnerianism. In the

8 Dalibor, 5 (1883), No. 10, p. 98.

9 Otakar Hostinský, “Richard Wagner †”, Dalibor, 5 (1883), No. 7, p. 62.

10 See Otakar Hostinský, "Fibichova Nevěsta Messinská: Pokračování” [Fibich’s Bride of Messina: Continuation], Dalibor, 6 (1884), No. 2, p. 22.

11 See Richard Wagner, Opera a drama [Opera and Drama] (Prague, 2002), p. 96-103.

12 Dalibor, 6 (1884), No. 13, p. 125.

13 See Břetislav Lvovský, "Dopisy ze Lvova” [Letters from Lvov], Dalibor, 7 (1885), No. 27, p. 267; and Břetislav Lvovský, "Dopisy z ciziny” [Letters from Abroad], Dalibor, 8 (1886), No. 20, p. 200.

14 Karel Knittl, “Nevěsta Messinská I.” Národní listy, 24 (1884), No. 86, [p. 3]. 
following articles about Nevěsta Messinská he did not conceal his reservations any longer: His opinions are best characterised by the statement, that "[...] due to the declamation, the singing is forgotten." ${ }^{15}$ Some of Knittl's censures were also surprisingly repeated by Fibich's supporter Václav Juda Novotný (1849-1922) who similarly lacked melodiousness. All the same, whatever the music critics' opinions were, nobody else but the audience decided the fate of Nevěsta Messinská. Spectators regarded the work as Wagnerian music drama arising out of a declamatory style wherein its incomprehension arose. Subscribers were captivated only by melodic parts of the work which only confirmed Smetana's words uttered five years earlier: "I recognized how little educated-musically educated-is our audience [...]." ${ }^{16}$ The director of the Národní divadlo František Adolf Šubert (1849-1915) after the second theatrical season even talked about the general unpopularity of Czech operas, which was soon reflected in the repertory. Owing to the audience's lack of concern Nevěsta Messinská was only played eight times throughout Fibich's life.

In terms of audience popularity, the first presentation of Wagner's work on the Czech stage met a completely opposite response. Also from the vantage point of Wagnerian reception research in the 1880s it seems that the premiere of Lohengrin in the Národní divadlo on 12 January 1885 was the most important event. We can follow calls for the production of some Wagner's opera from as early as the beginning of the 1880s. In the first August 1880 issue of Dalibor we read that several papers-among which were (apart from Dalibor) Národní listy, Politik [The Politician] and České noviny [Czech Gazette]-gave notice to the incoming management of the Národní divadlo that "[...] it must not ignore such an unexceptionable phenomenon-which Richard Wagner surely is-any longer." ${ }^{17}$ Yet in the same breath an author of the article added that not all of Wagner's works are suitable for our stage. He regarded the cycle Der Ring des Nibelungen even in its subject as foreign to the Czech repertory, and as appropriate operas he identified only Der Fliegende Holländer, Tannhäuser and Lohengrin. However, approximately three months earlier there also appeared in Dalibor reservations against Lohengrin, which was described as-for non-Germans-a less accessible, purely German saga. Antonín Dvořák also expressed his opinion of this opera in a similar spirit: "[...] because [Wagner] composed only with text, because he stood up for the greater German standpoint, Lohengrin should not have been played-I won't go there if Lohengrin is played, never." 18

Despite many similar censures the decision about the production of Lohengrin was probably made before the opening of the Národni divadlo in 1881. Thus we can assume that if the theatre did not burn down, the Czech audience would have experienced Wagner's opera a few years earlier. Also translations by Novotný had originated long since

15 Karel Knittl, “Nevěsta Messinská III.” Národní listy, 24 (1884), No. 95 [p. 5].

16 Otakar Hostinský, Vzpomínky na Fibicha [Memories of Fibich] (Prague, 1909), p. 76, footnote 1.

17 Dalibor, 2 (1880), No. 22, p. 169.

18 Jiří Kopecký (ed.), Zdeněk Fibich: Stopy života a díla [Zdeněk Fibich: Footprints of His Life and Work] (Olomouc, 2009), p. 84. 
the premieres. The Czech libretto of Lohengrin was published in 1882 and the translation of Tannhäuser even two years earlier, although it had already been completed since 1877 .

Voices against the postponement of the premiere of Lohengrin in Dalibor gradually grew stronger; in September 1881 one of the editors even accused the theatre's management of resorting to an excuse after it had probably announced that the postponement of the premiere was necessary because of the need for a bigger apparatus than the space of the Provisional Theatre allowed. However, confirmed information about the acquisition of Lohengrin however was not brought until the third issue of Dalibor in January 1884. The premiere, which occurred a year later, was greeted with enthusiasm by both audience and critics. Karel Teige (1859-1896) attributed the merit of Wagner's victory above all to Smetana who showed in his operas Tajemství [The Secret] and Libuše that Wagner's style is a higher theoretical principle which is usable in any nation's opera. According to Teige, thanks to Smetana " [...] anyone of us who knows [...] at least something about the matter does not regard as a political or national mistake the fact that we allowed Wagner's masterpieces to enter into our artistic sanctuary." ${ }^{19}$ But ardour among Dalibor's editors soon abated and performances of Lohengrin became one of the points which forged the basis of a long-term criticism of the Národní divadlo which reprehended it for a mostly superficial repertory based on external effects. In September part of Václav Vladivoj Zelený's (1858-1892) treatise Česká zpěvohra [Czech Opera] which was published in the same month's issue of Osvěta [Enlightenment] was reprinted in Dalibor. About Wagner's opera he wrote the following: "The enormous discrepancy between Lohengrin [and Carmen and Aida] did not cause any difference in the external reception of the novelty by the Czech audience. [...] The performance of Lohengrin itself was very unequal and the audience-knowing Wagner very well already-would not stand for a performance like that: yet in our theatre everything was accepted roundly with acclaim [...].” ${ }^{20}$ Finally, Zelený reached the conclusion that the success of Lohengrin did not hide an artistic victory (or intellectual progress), but a gratification of sensational demand. It is really very likely that only a few individuals among the critics and the "Smetanian" part of audience were able to estimate the real significance of the work, while for the others Lohengrin represented only an unusual spectacle based on a resplendent stage setting.

This situation was probably the same on the Czech stage in other cities where Wagner's operas were performed by Jan Pištěk's (1847-1907) theatre company. Information about the successful premiere of Lohengrin in Pilsen conducted by Karel Kovařovic surprised Prague cultural reporters in January 1887. We can attribute a great deal of merit for the enforcement of Wagner's work in Pilsen to Palla who, since the beginning of the decade, urged for the cultivation of local audiences by discourses or by performing excerpts from Wagner's operas within the scope of orchestral concerts. He also belonged among the contributors to Dalibor, in whose pages he published a more or less positive, albeit slightly reserved evaluation of the production. A year later, on 16 January 1888,

19 Karel Teige, “Wagnerův ‘Lohengrin’ I.” [Wagner’s Lohengrin I.], Dalibor, 7 (1885), No. 3, p. 21.

20

Dalibor, 7 (1885), No. 33, p. 326. 
the Czech premiere of Tannhäuser was realized in Pilsen, which Angelo Neumann, who owned the exclusive performing rights to Wagner's works in the Prague territory, refused to release to the Národní divadlo in 1885. Though Palla's review of the Pilsen Tannhäuser highlighted a splendid stage setting, a major emphasis was placed on a criticism of the performances of some soloists and of the insufficient instrumental and choral cast, which brought him to a contemplation of the fundamental question of the advisability of Wagner's works for the repertory of small theatres. This subject also became a focal point in the polemic of Franišek Karel Hejda (1865-1919) with Pištěk, which occured in Dalibor in May 1889. Hejda mostly criticised performances of Lohengrin by Pištěk’s theatre company in the spring of 1887 in České Budějovice and Mladá Boleslav, because in similar cases "[...] the consequence is not a popularization but profanity of Wagner." 21

We come to the conclusion, that the majority of Czech well educated music critics and artists perceived Wagner as an outstanding composer and opera reformer whose theoretical principles-thanks to the gradual promotion of Smetana's work-were comprehended as the foundation of Czech modern opera. National prejudices and reservations against the Teutonism of Wagner's works appeared in the press only sporadically; more often we encounter many superlatives in treatises on his personality or music. According to the publicists, the performance of operas by Wagner and other composers' modern foreign works on the Czech stage was the way which the Národní divadlo must follow in order to become a world-class theatre. But this way must not cause the marginalization of Czech vintage opera production as Zelený aptly illustrated in Dalibor from the end of the year 1884: "Nationality and art are treasures of the same value for us." 22 The above-mentioned opinions on Wagner's work were also shared by the slight, musically educated segment of Czech audiences which we know often attended the Prague German Theatre as well, and where they had a chance to acquaint themselves with Tristan und Isolde or the tetralogy Der Ring des Nibelungen. Nevertheless, Wagner's Teutonism in no way bothered the rest of the audience as the spectatorial success of Lohengrin proves. The reception of Richard Wagner's work thus tellingly illustrates the relative independence of musical life-above all in Prague-from the general social moods of the 1880s which were characteristic of a gradual increase of nationalistic tendencies.

${ }^{21}$ František Karel Hejda, "Hudební epištoly II.: Opera a koncert na českém venkově" [Music Epistles II.: Opera and Concert in the Czech Countryside], Dalibor, 11 (1889), Nos. 21 and 22, p. 166.

22 Václav Vladivoj Zelený, "První rok v Národním divadle” [The First Year in the National Theatre], Dalibor, 6 (1884), No. 44, p. 433. 


\section{Wagnerianismus in Tschechischen Ländern in achtziger Jahren des 19. Jahrhunderts}

\section{Zusammenfassung}

In den achtziger Jahren des neunzehnten Jahrhunderts können wir einige Ereignisse in den tschechischen Ländern hervorheben, die verschiedene Debatten um Richard Wagners Werk und seinen Einfluss auf die tschechische nationale Musik anregten. Zwischen diese Marksteine gehörten vor allem die Eröffnung des Nationaltheaters, die Aufführung von Parsifal in Bayreuth, Richard Wagners Tod, die Erstaufführung von Zdeněk Fibichs Braut von Messina, Lohengrins Premiere in dem Nationaltheater und die Aufführung von Lohengrin und Tannhäuser im Pilsner Stadttheater. Im Jahre 1881 wurden die „Kämpfe um Wagner" endgültig beendet. In diesem Jahr kam es zur letzten Entladung des „Antiwagnerianismus“, als František Pivoda das Buch $O$ hudbě Wagnerově (Über Wagners Musik) herausgab. Großer Teil der tschechischen Kritik und des Künstlerstandes nahm Richard Wagner in den achtziger Jahren als großen Komponisten und Opernreformator wahr, dessen theoretische Prinzipien dank der schrittweisen Durchsetzung von Bedřich Smetanas Werk als Ausgangspunkt der modernen tschechischen Oper verstanden waren. Nationale Vorurteile und Vorbehalte gegen das Deutschtum von Wagners Werken erschienen in der Presse nur sehr sporadisch. In den Aufführungen von Wagners Werken und von anderen modernen ausländischen Werken auf tschechischen Bühnen sah die Publizistik den Weg, den das Nationaltheater gehen muss, um ein Welttheater werden zu können. Ähnliche Ansichten hatte auch ein kleiner, musikalisch ausgebildeter Teil des tschechischen Publikums, von dem wir wissen, dass es nicht selten auch das Prager Deutsche Theater besuchte. Aber Wagners Deutschtum spielte nicht eine große Rolle auch bei der Mehrheit des übrigen Publikums, wie Lohengrins Zuschauererfolg erweist. Die Reflexion der Richard Wagners Werke illustriert also beredt die relative Unabhängigkeit des Musiklebens, vor allem in Prag, von allgemeinen gesellschaftlichen Stimmungen der achtziger Jahre, für die eine fortschreitende Zunahme der nationalistischen Tendenzen charakteristisch war.

\section{Wagnerianismus v českých zemích v osmdesátých letech 19. století}

\section{Shrnutí}

V osmdesátých letech 19. století lze v kontextu českých zemí vyzdvihnout několik událostí, které podněcovaly rozličné debaty o díle Richarda Wagnera a o jeho vlivu na českou národní hudbu. Mezi tyto milníky patřilo především otevření Národního divadla, uvedení Parsifala v Bayreuthu, Wagnerovo úmrtí, premiéra Fibichovy Nevěsty messinské, premiéra Lohengrina $\mathrm{v}$ Národním divadle a uvedení Lohengrina a Tannhäusera v plzeňském městském divadle. Roku 1881 byly definitivně ukončeny tzv. „boje o Wagnera“. V tomto roce 
došlo k poslednímu výraznějšímu výboji antiwagnerianismu, když František Pivoda vydal knihu $O$ hudbě Wagnerově. Velká část české hudební kritiky i umělců vnímala v osmdesátých letech Wagnera jako skladatelského velikána a reformátora opery, jehož teoretické zásady byly díky postupnému prosazování díla Bedřicha Smetany chápány jako východisko moderní české opery. Národnostní předsudky a výhrady proti němectví Wagnerových děl se v tisku objevovaly jen velmi sporadicky. V uvádění Wagnerových i dalších moderních zahraničních děl na českém jevišti viděla publicistika cestu, kterou se musí Národní divadlo ubírat, aby se stalo divadlem světovým. Podobné názory sdílela také nevelká, hudebně vzdělaná část českého obecenstva, o které víme, že nezřídka navštěvovala také pražské německé divadlo. Wagnerovo němectví však nehrálo velkou roli ani u většiny zbylého publika, jak dokazuje divácký úspěch Lohengrina. Recepce díla Richarda Wagnera tak výmluvně ilustruje relativní nezávislost hudebního života, především v Praze, na obecných společenských náladách osmdesátých let, charakteristických postupným nárůstem nacionalistických tendencí.

\section{Keywords}

Wagnerianism; Czech Lands; music criticism. 